\title{
The Natural Environment in The Adventures of Huckleberry Finn by Mark Twain
}

\author{
Firas Abdulkadhim Sadeq Alhilfi ${ }^{1,2}$ \\ ${ }^{1}$ School of Foreign Languages, English Department, Huazhong University of Science and Technology, Wuhan, China \\ ${ }^{2}$ Department of English, College of Education, Basra University, Basrah, Iraq
}

Email address:

fiarssadeq82@yahoo.com

\section{To cite this article:}

Firas Abdulkadhim Sadeq Alhilfi. The Natural Environment in The Adventures of Huckleberry Finn by Mark Twain. International Journal of Literature and Arts. Vol. 4, No. 2, 2016, pp. 25-29. doi: 10.11648/j.ijla.20160402.12

Received: February 23, 2016; Accepted: March 5, 2016; Published: April 5, 2016

\begin{abstract}
Mark Twain's The Adventures of Huckleberry Finn is one of the greatest novels in American literature. This paper attempts to outline the images of natural environment and the gap between the black and white people during the civil war. The essential part in this paper likens the way of living inside and outside the city and how Huck gets away from the hypocrisy of society and of the religious people. It illustrates Huck's adventures in the wild field.
\end{abstract}

Keywords: Natural Environment, Society, Hypocrisy, Freedom, Slave, Religion

\section{The Natural Environment}

The theme of nature in The Adventures of Huckleberry Finn is pervasive throughout the novel. There are many descriptions showing the relationship of nature to the human being in general and to Huck in particular. The river (the Mississippi river, Ohio), the storm and the stars are the major themes of natural environments in this novel. To what do these descriptions refer? It has been said that Huck Finn is fleeing from the conformity of the hypocrisy, the law and the monotony of society. He finds refuge with his friend, Jim, in the wilderness. During the descriptions of these kinds of natural figures, Mark Twain connects them with Huck's life and with society. According to Twain, the natural figures represent Huck's freedom. At the same time, society remains at the mercy of nature. Therefore, these are the main ideas in this paper.

"Another night when we was up at the head of the island, just before daylight, here comes a frame-house down, on the west side. She was a two-story, and tilted over considerable." (Twain 1999: 61)

The house is symbolic of man's established society in The Adventures of Huckleberry Finn. The natural forces of the Earth have the power to control society in some way. Throughout the novel, Huck always goes back to nature as a supporter of his thoughts, to keep his mind clear. He feels relaxed when he lies down beside the river and looks at the stars. Most of Huck's time is spent in the wild fields, surrounded by natural figures. It is an example of how nature can help him to deal with stress.

"A variety of studies over many years have shown faster recovery from stress in response to nature stimuli than built settings. These findings include a range of settings from nearby nature to wilderness. (Tetley 2014: 200)

Most people go into a natural environment to decrease their mental and physical exhaustion, restore their mental clarity and engender a mental sense of well-being, as well as physical relaxation. There are many instances where Huck chooses nature over civilisation. For instance, Huck runs away from the bad treatment he receives from his father. Although his father deals with Huck abusively, Pap seems respected in his society because he is a white man. Huck gets away from the hypocrisy of society and of the religious people, such as Miss Watson and her sister. The government's handling of him plays a major role in Huck's escape. Huck believes there is a safe place in nature and, in contrast, is in panic when he has to go back into civilisation: "It was kind of lazy and jolly, laying off comfortable all day, smoking and fishing, and no books nor study." (Twain 1999: 36)

Nature has positive and negative effects on people. The latter is represented by natural disasters such as storms, tsunamis, tornadoes, and other occurrences. The natural environment, according to Emerson, is regarded as a 
Transcendentalist force. This means that natural environments are a good cure for those who enjoy going into them to relieve bad moods and stress. In general, a city can be overcrowded and loud, so most workers would value natural environments for relaxation. This is what exactly Twain means as he depicts the hypocrisy of his society and he expresses this through his main characters like Huck and Jim.

"He first notes that when one wants to be alone, one can look at the stars because they inspire a feeling of respect, because they remain inaccessible. He adds: If the stars should appear one night in a thousand years, how would men believe and adore; and preserve for many generations the remembrance of the city God which had been shown. All the objects in nature entail such an impression of wisdom, happiness, and simplicity." (Dolan 2009: 81)

"As a balance of too much directed attention, nature offers intrinsic interest and a sense of fascination. The restorative effect of a natural environment (whether time is a wilderness setting or a walk in a local nature preserve) leads to renewed attention and positive affect. For example, after 45 minutes of taxing mental work, a walk in a natural area led to better recovery than a walk in an urban area or reading magazines and listening to music." (Barclay 2010: 45)

Huck discovers that nature is a safe haven and a hiding place, a place where he can go and not be found if he does not want to be found.

"So he watched out for me one day in the spring, and catched me, and took me up the river about three miles in a skiff, and crossed over to the Illinois shore where it was woody and there warn't no houses, but an old log hut in a place where the timber was so thick you couldn't find it if you didn't know where it was." (Twain 1999: 25)

It is confusing to the reader, as we know that Pap had taken his son to the woods, but Huck did not like that place, yet both of them are an integral part of a nature. This is ironic because Huck was not taken there to spend time relaxing, having fun and exploring with his father, but was kidnapped (forced) by his father and taken away to a cabin. This could twist Huck's view of nature, but Huck prefers being there rather than living with the widow in the city. As mentioned above, both Huck and Jim live in society, but Huck feels that he does not know how to act when 'confined' in the city.

"by and by it got sort of lonesome, and so I went and set on the bank and listened to the current swashing along, and counted the stars and drift-logs and rafts that come down, and then went to bed." (Ibid: 51)

\section{Nature as Huck's Comfort}

The natural environment plays an essential part in showing the difference between society and nature. Calming sounds provide Huck the serenity for which he looks. This is a clear representation of how Huck feels free on the outside of his society. During the journey, Huck sees the beauty and freedom of nature, which attracted him to being outside and far from the city: "Not a sound any Where's, just like the whole world's asleep, only sometimes the bullfrogs a- cluttering, maybe." (Twain 1999: 135) Huck describes how beautiful and serene the night is outside. He always sees things as more attractive and more calming in nature than in the city.

"It was a monstrous big river down there-sometimes a mile and a half wide; we run nights, and laid up and hid daytimes; soon as night was gone we stopped navigating and tied upnearly always in the dead water under a tow head; and then cut young cottonwoods and willows, and hid the raft with them." (Ibid: 93)

There is a wonderful explanation of the vastness of the Mississippi River, where he considers the river as if it is alive. He tells how the river is weaving, much like his life. Twain uses these descriptions to relate to Huck's struggle and the journey of his life.

"When I got there it was still and Sunday-like, and hot and sun-shiny; the hands was gone to the fields; ad there was them kind of faint dronings of bugs and flies in the air that makes it seem so lonesome and like everybody's dead and gone; and if a breeze fans along and quivers the leaves it makes you feel mournful, because you feel like it's spirits whispering - spirits that's been dead ever so many years - and you always think they're talking about you. As a general thing it makes a body wish he was dead, too, and done with it all." (Ibid: 228)

Twain also used Huck's view of nature as a forewarning of what was to come with nature and the sequence of the novel. Sometimes Huck views nature as aggressive, dangerous and unforgiving. He respects nature rather than only enjoying its existence because he knows very well it can change according to the environment at any moment. This shows how people, just like nature, can alter their attitude from enemies to fellows. Twain wants to illustrate the form of his society by showing this kind of change from enemies to fellows. He says that even American society can change from bad behaviour to better behaviour, just like Huck's ideas. At the beginning of the novel, he thinks all the blacks are the same but, after forming a close relationship with Jim, he changes his ideas. American society should change its opinions about slaves and poor people because all people are the same, all are human beings. There is no difference between black and white and rich and poor. From Twain's point of view, the Mississippi River is a symbol of freedom to oppressed people. Huck and Jim are alone on their raft; they do not have any idea about anything. The river transports them toward freedom: for Huck, away from his abusive and feckless father and the restricting civilisation of St Petersburg; for Jim, towards the free states. Huck and Jim are changing their attitudes about each other, with little prompts. "Huck's fictions are lies against time, against an impossible father, against society and history" (Bloom 2007: 3 ). Everything in nature happens for a reason, even a sudden alteration.

"I couldn't get the chimbly; it was too narrow. The door was thick, solid oak slabs." (Twain 1999: 37) Huck feels stuck, physically, in the cabin with his father. He cannot get out and away from his father; spiritually, he feels very sorry 
about his father and himself. He cannot escape his father's abuse. He senses that he will never become sufficiently educated to live on his own. This produces an image that nature is a safe haven because it saved Huck and Jim from spiritual and physical mistreatment. Nature teaches Huck a valuable lesson in The Adventures of Huckleberry Finn, i.e., everything takes place for a reason. Occurrences in the natural environment, such as stormy disasters, flood deaths, and injustice are parts of life that will always be there. Storms, stars, rivers and other natural environments help everyone in real life. No one has the ability to control everything as he or she supposes, and everything happens for a reason. It is used as a pressure-relieving device. Some studies show that the outdoors, which is far away from crowds and society, helps people to recover quickly and decrease stress. Huck shows this to the people who spend all their time working and this is one of the simple facts why Twain creates his character, Huck, to love nature so much. Because of Huck's father, Huck has not had an irregular life, but he turns to nature to find serenity outside the city. This is shown in the river scene where he is lying beside the river and looking for the star and admiring the scenes of the river. Listening to the sound of nature, whether it is the sound of the waves or the sound of the trees is a beautiful thing. Nature is definitely a good cure for people and it is used to rejuvenate the mind and body (spiritually and physically) but some do not like to spend much time in nature or outside their houses. This is exactly what Huck does in the novel. Huck flees from the city to nature, wishes to survive and live in nature, because he can really be himself in that element. Some people, such as the Grangerfords, live in very big mansions, full of beautiful and expensive ornaments, but they are very unhappy. Most of the time they are stressed and miserable, because they feud with each other's families. Sometimes they go together to the church, but they are still willing to fight; even the church, a place for peaceful reflection, is a stressful and uncomfortable environment. Emerson believes that nature is the centre of all happiness because God created it. He believes natural environments are significant, and we should learn to appreciate them. "At one point he produces a memorable image of Mississippi night, glittering with the visual and tactile" (Bloom 2005: 54)

"I was powerful glad to get away from the feuds, and so was Jim to get away from the swamp. We said there warn't no home like a raft after all. Other places do seem so cramped and smotherly, but a raft don't. You feel mighty free and easy and comfortable on a raft." (Twain 1999: 134)

\section{Symbols of Natural Forces in Huckleberry Finn}

Twain uses natural environments and the forces of nature as symbols in his novel. The river is the most highlighted and most powerful symbol in The Adventures of Huckleberry Finn. It represents freedom, individuality and life in the wild.
Huck flees the crowded society and civilisation to live on the river. He leaves everything in his life and comes through the adventure with his friend. T. S. Eliot said:

"gives the book its form, but for the river, the book might be a sequence of adventures with a happy ending. A river, very big and powerful river, is the only natural force that can wholly determine the course of human peregrination. Thus the river makes the book a great book." (Eliot 1950: 7-16)

As mentioned previously Huck Finn flees from the hypocrisy of his society and from his abusive father. $\mathrm{He}$ considers the river and the wild as his home. Jim also runs away from the same society, considering the river is a saviour from that society and as a means of transportation to reach his family. The river also takes Jim and Huck past Cairo and safety and ever deeper into slave country but for this it is in no way to blame, unless it is seen in an anthropomorphic light. (Wieck 2003: 76)

The fog is a sign of hindrance, and how problems can sometimes make it complicated to accomplish one's aims: "I see the fog closing down, and it made me so sick and scared I couldn't budge for most a half a minute it seemed to me and then there warn't no raft in sight; you couldn't see twenty yards."(Twain 1999: 91) This is an example of how life can cloud vision and you cannot see what you are going through until you get to the other side. The lack of clarity in the scene means they cannot decide what they are going to do next, where to go or what they are going to see. When the fog arrives in the novel, it blankets everything, and Huck and Jim unknowingly pass their destination of Cairo; as the proverb says man does not attain all his heart's desires for the winds do not blow as the vessels wish.

\section{Nature Versus Society}

"The Widow Douglas she took me for her son, and allowed she would sivilize me; but it was rough living in the house all the time, considering how dismal regular and decent the widow was in all her ways. (Twain 1999: 13)

Huck will not become free if he stays in the city, because he must follow social conventions and be 'civilised'. The Widow Douglas puts him under strict orders so he will look like a normal boy, suitable for society. She is also one of the characters that follow the discriminatory restrictions in her society. Huck finds it hypocritical that she forbids him to smoke while she continues the practice of using tobacco. $\mathrm{He}$ knows that she is a hypocritical woman because she does not follow what she herself says.

"Pretty soon I wanted to smoke, and asked the widow to let me. But she wouldn't. She said it was a mean practice and wasn't clean, and I must try to not do it any more... And she took snuff, too; of course that was all right, because she done it herself." (Ibid: 15)

The contrast between nature and society is a crucial theme in The Adventures of Huckleberry Finn. The plot of this novel emphasises the difference between nature and society. Huck and his friend, Tom, have found a large amount of money in a cave, so they become very rich. After 
Huck stays with Widow Douglas, who attempts to 'civilise' him, his drunkard father, Pap, returns. Huck is in anguish and abused by his father, so he finally decides to escape. Huck fakes his own death by killing a pig and escapes to Jackson's Island, where he stays until he encounters Jim, who is Widow Douglas's slave. From that first moment, Jim reveals that he is escaping on the Mississippi river to free his family; Huck decides to go along with him. Through the adventures of both of them on the river, Huck grows in maturity and morality. He is able to differentiate between nature and society, and what each side represents. Nature relates to anything in the novel that is free. It includes Jackson's Island, the Mississippi River, the Ohio River, the storm and the forests along the river. They symbolise freedom, serenity and peace, and provide an environment without human interference. Sometimes this is known as the 'river versus shore' theme, where the river represents nature, and the shore represents society.

“... I do believe he cared just as much for his people as white folks does for their'n. It don't seem natural, but I reckon it's so... He was a mighty good nigger, Jim was." (Twain 1999: 170)

Huck realised that there is no difference between the blacks and whites: Jim is like him and like any other human being. While living with Jim, he saw him as more than a slave and even as a father figure. This opinion opened him up to seeing $\mathrm{Jim}$ as an equal and a friend. For other people in American society, this is very different. Sometimes the relationship between the white people symbolises the corruption and hypocrisy of society, for example, Duke and King, Ms Watson, Tom, the Grangerfords, and the Arkansas mob. Society frustrates the serenity of the natural environment by creating the opposite effect. Instead of showing peace and relaxation, society creates pressure and confusion, which is represented by all the kinds of humans mentioned above in all of their several states of madness, whether it is greed, insecurity, hypocrisy, terror, or prejudice. All of these force Huck to make important choices, and display how far he has grown when confronted with these choices. Despite his happiness in the wild and watching the natural environment, society is where his morals are truly tested.

Finally, Twain shows the readers of his novel that Huck learns how to find beauty and love in nature throughout the story during his relationship with the people around him, especially with Jim, who gives him most of the moral lessons indirectly, through the love and the sacrifice of himself. Jim cannot control many people, but he can shape situations on an abstract level. He at once assimilates the "dream" of the fog into his ruling mental system (his religion of superstition). When Huck tells him the truth, that it was not a dream, Jim, after great effort, assimilates the matter to his self-respect, a major part of his conception of himself (Carrington 1976: 56). He realises what American society is like throughout the novel and what religious and poor people look like. Huck sees nature as the best way to leave society and civilisation and his journey down the river confirms this view of nature in the novel. The conflict between nature and society is a theme depicted throughout Huckleberry Finn. Huck does not want to be civilised by the religious figures of the society and realises that nature is the right place for him and that following his conscience is the correct thing to do. There are many reasons why Huck leaves society. Huck sees the ridiculous violence of Colonel Sherburn's shooting of the poor Boggs. He sees how wrong society is after that. He also sees the irrationality of a feud, which is based on unknown and unfounded principles, as seen through the Grangerfords and Shepherdsons. He also understands the reaction of society from his beliefs when he accepts going to Hell and elects to help Jim. From that Jim and Huck establish a sense of trust and the two run away are mutually protective of each other despite Jim's legal importence. Between them a force of racial integrationtake place. (Williams 1992: 233) Huck sees how greedy humans can be through the surreptitious schemes of the King and Duke: "Aunt Sally said she wants to adopt me... No, I've been there before." (Twain 1999: 296) This is the last sentence in the novel, one can understand that Huck not only invests his time in nature to periodically run away from society, Huck wants to run away from the corruption of society.

Nature is a peaceful and serene environment that allows both characters to escape from the hardships of their lives (slavery and Pap's abuse). It makes them forget the suffering inside society and how bad people deal with each other. This is not just for the poor, but for all levels of society. In that natural place they feel happy and free to do what they want. Jim is seen as an equal (despite his skin colour) by his friend Huck. Despite Huck's remaining racist beliefs, for the most part, they are friends, and race matters less when they are freely floating on the river beside the wild fields. The river is a place where Huck is allowed to make his own choices and learn his own lessons without the stress and judgement of society.

\section{Conclusion}

Most of the people in Mark's society are hypocritical, even the religious figures. In the novel Miss Watson and her sister the Widow Dougles are fine examples. People try to cover up many imperfect things in the American society, especially in the Southern. The natural environment is also one of the important themes to distinct the difference between the society and the nature. Some of the natural phenominenants in the environment can make lots of changes to the people's lives. Mark Twain used them to show the changes that occurred in the natural environment. The natural environment helps relaxation and it is a soothing experience for human beings who try to run away from the open society to the nature to find their inner peace. Nature itself has a strong power to delimit their fancies of the society and its people as one of the advantages of the nature. Twain reveals the corruption and selfishness of society throughout his novel. By using slavery and the structure of society, he points out the negative image of the American society. 


\section{References}

[1] Twain, Mark. 1999. Adventure of Huckleberry Finn. New York: Norton \& Company.

[6] Bloom, Harold. 2005. The Adventures of Huckleberry Finn. U. S. A: Chelsea House Publisher.

[7] Bloom, Harold. 2007. The Adventures of Huckleberry Finn. Bloom's Modern Critical Interpretations. New York: Infobase Publishing.

[2] Barclay, Patricia. 2010. Mediation Techniques. London: International Bar Association press.

[3] Dolan, Neal. 2009. Emerson's Liberalism, Studies in American Thought and Culture. University of Wisconsin Press.

[4] Tetley, David Alfred. 2014. You Might Be a Christian and Not Even Know It!. Balboa Press.

[8] George C. Carrington. 1976. The Dramatic Unity of Huckleberry Finn. Columbus: Ohio State university press.

[9] Carl F. Wieck. 2003. Refiguring Huckleberry Finn. U. S. A: University of Georgia Press.

[10] Williams, Kenny J. 1992. Mark Twain's Racial Ambiguity. N. C. and London: Duke University Press.

[5] Eliot, T. S. 1950. Introduction to The Adventures of Huckleberry Finn. London: The Cresset Press. 